\title{
Remote Sensing Technology Applications in Forestry and REDD+
}

\author{
Kim Calders ${ }^{1, *(\mathbb{D})}$, Inge Jonckheere ${ }^{2}$, Joanne Nightingale ${ }^{3}$ and Mikko Vastaranta ${ }^{4}(\mathbb{D}$ \\ 1 CAVElab-Computational \& Applied Vegetation Ecology, Faculty of Bioscience Engineering, Ghent \\ University, 9000 Ghent, Belgium \\ 2 FAO of the United Nations, Forestry Department, viale delle Terme di Caracalla, 00153 Roma, Italy; \\ inge.jonckheere@fao.org \\ 3 Earth Observation, Climate and Optical Group, National Physical Laboratory, Teddington TW11 0LW, UK; \\ joanne.nightingale@npl.co.uk \\ 4 School of Forest Sciences, University of Eastern Finland, Yliopistokatu 7, P.O.Box 111, FI-80101 Joensuu, \\ Finland; mikko.vastaranta@uef.fi \\ * Correspondence: kim.calders@ugent.be
}

Received: 4 February 2020; Accepted: 5 February 2020; Published: 7 February 2020

\begin{abstract}
Advances in close-range and remote sensing technologies drive innovations in forest resource assessments and monitoring at varying scales. Data acquired with airborne and spaceborne platforms provide us with higher spatial resolution, more frequent coverage and increased spectral information. Recent developments in ground-based sensors have advanced three dimensional (3D) measurements, low-cost permanent systems and community-based monitoring of forests. The REDD+ mechanism has moved the remote sensing community in advancing and developing forest geospatial products which can be used by countries for the international reporting and national forest monitoring. However, there still is an urgent need to better understand the options and limitations of remote and close-range sensing techniques in the field of degradation and forest change assessment. This Special Issue contains 12 studies that provided insight into new advances in the field of remote sensing for forest management and REDD+. This includes developments into algorithm development using satellite data; synthetic aperture radar (SAR); airborne and terrestrial LiDAR; as well as forest reference emissions level (FREL) frameworks.
\end{abstract}

Keywords: airborne laser scanning; terrestrial laser scanning; remote sensing; REDD+; forestry

Forest ecosystems cover approximately $31 \%$ of the world's land area, with a total forested area of approximately 4 billion hectares [1]. Forests play an important role in today's society and serve as a source for the production of paper products, lumber and fuel wood. In addition, forests produce freshwater from mountain watersheds, purify the air, offer habitat to wildlife and offer recreational opportunities among many other ecosystem services. To keep forests productive, and ecological and recreational functions balanced, accurate and precise information about forest structure and its biophysical parameters are needed for supporting informed decision making and sustainable management [2].

Many decisions made by natural resource managers and policymakers regarding forests are poorly linked with the spatial scales covered by conventional forest inventory methods. Remote sensing is seen as one of the key data sources to fill existing forest monitoring information gaps, particularly in many developing countries [3]. Information retrieved through remote sensing, especially through space- and airborne acquisition methods, can offer a synoptic view over large or inaccessible areas. The Forest Resources Assessment [4] supports global tree cover and forest land use monitoring. Monitoring programs implement a systematic framework to obtain information about changes in forest cover and 
forest land use changes on a global scale. On the global scale, the land use of approximately 12 million hectares of forest ecosystems changed in 2018 (World Resources Institute), making geographically extensive and spatially detailed forest monitoring an important task. Furthermore, deforestation and forest degradation account for about $12 \%$ of global anthropogenic carbon emissions, which is second only to fossil fuel combustion $[5,6]$. However, this estimate is quite uncertain due to inadequate estimates of forest carbon stocks and is expected to range from $6 \%$ to $17 \%$. Carbon emissions are partially compensated by forest growth, forestation and the rebuilding of soil carbon pools following afforestation. However, the global distribution of terrestrial carbon sinks and sources is highly uncertain. Initiatives constraining the inaccuracy in forest carbon estimates are essential to the development of new techniques and methodologies for supporting information needs of effective forest management and future climate mitigation actions $[7,8]$.

Advances in close-range and remote sensing technologies drive innovations in forest resource assessments and monitoring at varying scales. Data acquired with airborne and spaceborne platforms provide us with higher spatial resolution, more frequent coverage and increased spectral information. Recent developments in ground-based sensors have advanced 3D measurements, low-cost permanent systems and community-based monitoring of forests. REDD+ is a climate change mitigation programme that is supported by implementation initiatives such as the United Nations Collaborative Programme on Reducing Emissions from Deforestation and Forest Degradation (UN-REDD) [9]. The commitments and requirements for countries to participate in the REDD+ mechanism have encouraged the remote sensing community in advancing and developing forest geospatial products that can be used by countries for national forest monitoring and international reporting. However, there still is an urgent need to better understand the methodological options and limitations of remote and close-range sensing techniques in the field of forest degradation and change monitoring.

This Special Issue contains 12 studies that provided insight into new advances in the field of remote sensing for forest management and REDD+. This included developments into (1) algorithm development using satellite data [10-16]; (2) synthetic aperture radar (SAR) [11,17]; (3) airborne [18] and terrestrial [19,20] LiDAR; and (4) forest reference emissions level (FREL) frameworks [21]. Chen et al. [11] combine texture characteristics and backscatter coefficients of Sentinel-1 with multispectral information derived from Sentinel-2 and traditional field inventory data to develop above-ground biomass (AGB) prediction models using machine learning. Shen et al. [12] apply machine learning techniques, using Landsat-5 Thematic Mapper (TM) and Landsat-8 Operational Land Imager (OLI) images to monitor the five-year change in AGB over three regions with different topographic conditions in Zhejiang Province, China. Li et al. [13] test various statistical frameworks on Landsat-8 OLI data to improve AGB mapping over a subtropical forest in Western Hunan in Central China. Zhang et al. [17] explore the use of advanced land observing satellite-2 (ALOS-2) phased array-type L-band synthetic aperture radar (PALSAR-2) full polarimetric SAR data to estimate forest growing stock volume in a region with challenging terrain conditions. Blinn et al. [16] derive leaf area index (LAI) from Landsat-7 (ETM+) and Landsat-8 (OLI) vegetation indices. Zhao et al. [10] use machine learning on both structural and spectral indices from QuickBird multispectral and panchromatic images to map forest canopy cover. Spracklen and Spracklen [14] demonstrate the use of machine learning with Sentinel-2 images for identifying old-growth forests in Europe. Gigovic et al. [15] create a remote sensing (MODIS, Landsat-8 OLI and Worldview-2) derived forest inventory map to train a machine learning algorithm to predict forest fire susceptibility.

Random forest (RF) has been the most popular machine learning algorithm to link remote sensing data to forest structural attributes such as AGB [11,12], canopy cover [10] or forest fire susceptibility [15]. Spracklen and Spracklen [14] apply RF to identify old-growth forests using remote sensing data. Chen et al. [11] and Gigovic et al. [15] test different machine learning approaches for predicting AGB. Whereas Chen et al. [11] identify that RF was not always the most suitable method for predicting and mapping AGB, Gigovic et al. [15] obtain comparable results between RF and support vector machine approaches. 
The LiDAR studies in this Special Issue present work on a regional scale using airborne LiDAR [18], as well as tree-level assessment of LAI [19] and AGB [20] from terrestrial LiDAR. Often, LiDAR is not available over large continuous areas but can be essential for the calibration and validation (cal/val) of many forest map products that have been derived using coarser resolution satellite observations. Duncanson et al. [22] argue that spatially continuous maps of forest attributes are essential for programs as REDD+, but their accuracy might be challenged if appropriate reference data, such as airborne or terrestrial LiDAR, is not available for calibration and validation. Advances in remote and close-range sensing techniques will be critical to implement scientific output in developing a forest reference emissions level (FREL) for countries in the REDD+ context to account for likely future developments. In this Special Issue, Pirker et al. [21] demonstrate this approach for Southern Cameroon. Their work identifies the priorities for creating and improving the necessary data, information and infrastructure for improving each element of the FREL with the ultimate objective of developing a FREL for a performance-based payment program.

Finally, we would like to thank the authors of the Special Issue for their contributions and additionally thank the reviewers and the Forests Editorial Office for conducting a high-quality review process for all of the published papers. We hope that this Special Issue will foster the remote sensing science and policies related to forestry and REDD+.

Author Contributions: All authors have read and agreed to the published version of the manuscript. Writing—original draft preparation, K.C.; writing — review and editing, all the authors.

Conflicts of Interest: The authors declare no conflict of interest.

\section{References}

1. United Nations. The Sustainable Development Goals Report. 2017. Available online: https://unstats.un.org/ sdgs/files/report/2017/TheSustainableDevelopmentGoalsReport2017.pdf (accessed on 6 February 2020).

2. Waring, R.H.; Running, S.W. Forest Ecosystem Analysis at Multiple Time and Space Scales, 3rd ed. 2007, pp. 1-16. Available online: https://booksite.elsevier.com/samplechapters/9780123706058/Sample_Chapters/ 02 \{\}Chapter_1.pdf (accessed on 6 February 2020).

3. Romijn, E.; Herold, M.; Kooistra, L.; Murdiyarso, D.; Verchot, L. Assessing capacities of non-Annex I countries for national forest monitoring in the context of REDD+. Environ. Sci. Policy 2012, 19-20, 33-48. [CrossRef]

4. Food and Agriculture Organization of the United Nations. Global Forest Resources Assessment 2015: How are the World's Forests Changing? 2nd ed.; Food \& Agriculture Organization of the United Nations: Rome, Italy, 2018; ISBN 9789251092835.

5. Van der Werf, G.R.; Morton, D.C.; DeFries, R.S.; Olivier, J.G.J.; Kasibhatla, P.S.; Jackson, R.B.; Collatz, G.J.; Randerson, J.T. $\mathrm{CO}_{2}$ emissions from forest loss. Nat. Geosci. 2009, 2, 737-738. [CrossRef]

6. Le Quéré, C.; Raupach, M.R.; Canadell, J.G.; Marland, G.; Bopp, L.; Ciais, P.; Conway, T.J.; Doney, S.C.; Feely, R.A.; Foster, P.; et al. Trends in the sources and sinks of carbon dioxide. Nat. Geosci. 2009, 2, 831-836. [CrossRef]

7. Houghton, R.A.; Hall, F.; Goetz, S.J. Importance of biomass in the global carbon cycle. J. Geophys. Res. Biogeosci. 2009, 114, G00E03. [CrossRef]

8. Pan, Y.; Birdsey, R.A.; Fang, J.; Houghton, R.; Kauppi, P.E.; Kurz, W.A.; Phillips, O.L.; Shvidenko, A.; Lewis, S.L.; Canadell, J.G.; et al. A large and persistent carbon sink in the world's forests. Science 2011, 333, 988-993. [CrossRef] [PubMed]

9. United Nations. United Nations UN-REDD Programme. 2014. Available online: www.un-redd.org (accessed on 6 February 2020).

10. Zhao, Q.; Wang, F.; Zhao, J.; Zhou, J.; Yu, S.; Zhao, Z. Estimating Forest Canopy Cover in Black Locust (Robinia pseudoacacia L.) Plantations on the Loess Plateau Using Random Forest. Forests 2018, 9, 623. [CrossRef]

11. Chen, L.; Ren, C.; Zhang, B.; Wang, Z.; Xi, Y. Estimation of Forest Above-Ground Biomass by Geographically Weighted Regression and Machine Learning with Sentinel Imagery. Forests 2018, 9, 582. [CrossRef]

12. Shen, A.; Wu, C.; Jiang, B.; Deng, J.; Yuan, W.; Wang, K.; He, S.; Zhu, E.; Lin, Y.; Wu, C. Spatiotemporal Variations of Aboveground Biomass under Different Terrain Conditions. Forests 2018, 9, 778. [CrossRef] 
13. Li, C.; Li, Y.; Li, M. Improving Forest Aboveground Biomass (AGB) Estimation by Incorporating Crown Density and Using Landsat 8 OLI Images of a Subtropical Forest in Western Hunan in Central China. Forests 2019, 10, 104. [CrossRef]

14. Spracklen, B.D.; Spracklen, D.V. Identifying European Old-Growth Forests using Remote Sensing: A Study in the Ukrainian Carpathians. Forests 2019, 10, 127. [CrossRef]

15. Gigović, L.; Pourghasemi, H.R.; Drobnjak, S.; Bai, S. Testing a New Ensemble Model Based on SVM and Random Forest in Forest Fire Susceptibility Assessment and Its Mapping in Serbia's Tara National Park. Forests 2019, 10, 408. [CrossRef]

16. Blinn, C.E.; House, M.N.; Wynne, R.H.; Thomas, V.A.; Fox, T.R.; Sumnall, M. Landsat 8 Based Leaf Area Index Estimation in Loblolly Pine Plantations. Forests 2019, 10, 222. [CrossRef]

17. Zhang, H.; Zhu, J.; Wang, C.; Lin, H.; Long, J.; Zhao, L.; Fu, H.; Liu, Z. Forest Growing Stock Volume Estimation in Subtropical Mountain Areas Using PALSAR-2 L-Band PolSAR Data. Forests 2019, 10, 276. [CrossRef]

18. Zörner, J.; Dymond, J.R.; Shepherd, J.D.; Wiser, S.K.; Jolly, B. LiDAR-Based Regional Inventory of Tall Trees-Wellington, New Zealand. Forests 2018, 9, 702. [CrossRef]

19. Deng, Y.; Yu, K.; Yao, X.; Xie, Q.; Hsieh, Y.; Liu, J. Estimation of Pinus massoniana Leaf Area Using Terrestrial Laser Scanning. Forests 2019, 10, 660. [CrossRef]

20. Lau, A.; Calders, K.; Bartholomeus, H.; Martius, C.; Raumonen, P.; Herold, M.; Vicari, M.; Sukhdeo, H.; Singh, J.; Goodman, R.C. Tree Biomass Equations from Terrestrial LiDAR: A Case Study in Guyana. Forests 2019, 10, 527. [CrossRef]

21. Pirker, J.; Mosnier, A.; Nana, T.; Dees, M.; Momo, A.; Muys, B.; Kraxner, F.; Siwe, R. Determining a Carbon Reference Level for a High-Forest-Low-Deforestation Country. Forests 2019, 10, 1095. [CrossRef]

22. Duncanson, L.; Armston, J.; Disney, M.; Avitabile, V.; Barbier, N.; Calders, K.; Carter, S.; Chave, J.; Herold, M.; Crowther, T.W.; et al. The Importance of Consistent Global Forest Aboveground Biomass Product Validation. Surv. Geophys. 2019, 40, 979-999. [CrossRef] [PubMed]

(C) 2020 by the authors. Licensee MDPI, Basel, Switzerland. This article is an open access article distributed under the terms and conditions of the Creative Commons Attribution (CC BY) license (http://creativecommons.org/licenses/by/4.0/). 